\title{
In This Issue. . .
}

As we assemble International Politics, Vol. 39, No. 1 for March 2002 in the autumn of 2001, we cannot ignore global events that are as terrible as they are profound. Those who write for, read, and edit scholarly journals on international relations have been affected deeply by a series of events that seemed to begin on September 11, 2001. Of course, they did not begin on one day in one year.

Terrorism has been part of the landscape of international politics for, perhaps, millennia. The intermingling of such acts with religious fundamentalism, however, is a new and deadly twist.

At International Politics we have followed frequently and in-depth various elements that form the background to a world in which mega-terrorism emerges. We've read Robert E. Harkavy's assessment (Vol. 37, No. 3, September 2000) that explored how defeat, and subsequent humiliation, enrages and leads to the next round of violence. In Vol. 38, No. 1 (March 2001), Amalendu Misra, too, explored the conundrum in Kashmir that pits Pakistan versus India, a zone certainly linked by geography, intensity and terrorist events to what was seen in late 2001. Further, in Vol. 37, No. 2 (June 2000), David Gibbs focused on Afghanistan specifically, with a retrospective analysis of works about the Soviet invasion and Mujahadeen resistance.

We cannot, nor ought we, track global events. Scholarly journals are not in that business. Yet, even as we present to you this first issue of 2002, International Politics is cognizant of the topicality of articles in this and future collections.

Terribly clear, for example, is the vulnerability of states - even larger, powerful ones - to non-state actors. In our pages, we've devoted substantial attention to the new milieu for global politics - still populated by states, sovereignty and territory, and still acting with power for perceived national interests but, much more than ever before, acting on a stage crowded with other entities.

In Vol. 39, No. 1, we revisit and expand such attention via articles by Lars K. Hallstrom (St. Francis Xavier University), who addresses a seductive theoretical alternative to a statecentric international relations, and Lawrence Serewicz, who considers how when states' monopoly of violence is no longer assured they adapt by reaching for other techniques including private military companies.

Hallstrom identifies and critiques the rhizomic model - the global system $a$ la an environmental whole - as an alternative "new IR.” Considering works by Deleuze, Guattari, and Kuehls among others, Hallstrom cautions that a replacement of state and sovereignty by environmentally-grounded theory establishes a new primacy, truth and reality that are no less hegemonic than the old. That it is natural makes the rhizome all the more, says Hallstrom, seductive. His analysis of such a still-emerging, but widespread, theoretical alternative is not reassuring. That the old, traditional international relations is a field of substantial lacunae is evident; explaining a world in which movements attack iconic symbols of state power with hijacked domestic airliners requires new language, new framing, new prisms. Whether rhizomic understanding offers such an alternative is unclear; 
Hallstrom's essay warns us against too much confidence that an eco-ethic is necessarily the solution to IR's theoretical needs.

Lawrence Serewicz, too, considers the shifting sands of the international system and the erosion of states' monopoly on the means of violence. Sub-state military threats, and supra-state politico-economic challenges, yield challenges to sovereignty. Globalization, he says, may come to states' rescue, in a manner of speaking, by providing an added and alternative source of force - private international security companies - on which the state can lean. Put another way, states adapt to a globalized environment, acknowledging the limited fungibility of their own armies, while seeing advantages in the ongoing military revolution.

Theory that tries to bury the state or assumptions that an ebbing monopoly of force will constrain state options are both premature. The state's flexibility and adaptability, and the questionable seductivity of alternative theoretical frameworks, suggest that the "new" international relations cannot cut intellectual ties with traditional components. Other models may be no less insistent and hegemonic, while states' capacities for protecting residual sovereignty through other means should not be underestimated.

Two of this issue's articles strongly link history to contemporary global dynamics. Harry Ritter (Western Washington University), writing about the rise, fall and return of liberalism in Germany and Austria, refers evocatively to the Third Reich "cling[ing] to the two German-speaking states like the shadows of expressionist cinema." Following the gestation and trials of Central European liberalism in the 18th, 19th and 20th centuries, Ritter brings us to today's populist challenges (e.g., Jörg Haider in Austria) and offers his judgment that the deep roots of liberalism cannot be easily dislodged by such transient appeals. Through such political history, we learn both how and why liberalism retained longstanding influence despite nationalist and fascist periods and limited electoral appeal after World War II. Historically weak, yet with lasting impact, says Ritter as he judges German and Austrian liberalism.

Historical reflections inform Kjell Engelbrekt's (University of Stockholm) analysis of the European Union's approach to an enlargement that would incorporate countries from the former-communist "eastern" half of the continent. Byzantium's approach to barbarians in the second half of the first millennium (500-1000 A.D.) is, to Engelbrekt, parallel in many respects to the EU's process of enlargement. A "relentlessly self-centrist" position vis-à-vis everyone non-Byzantine - an imperial policy-making, says Engelbrekt - yields an indifferent, arrogant and insensitive stance towards applicant countries. Like Constantinople's sense as opposed to the Hinterlands, EU members and the EU Commission adopt positions in specific policy arenas such as agriculture subsidies, immigration and labor markets that evince Byzantine attitudes and threaten the entire enlargement process.

These historical lenses tell us a great deal about where we are today, and why. If democracy in Central Europe has resiliency, and can "handle" a Haider, the lengthy path by which liberal thought became engrained even if not politically powerful is worthy of careful exploration. But, lest we assume that the integrative role of the EU is entirely benign, parallels between Brussels and Byzantium are instructive. Of what are we "composed" today in terms of values and institutions? The answers, say Ritter and Engelbrekt, sometimes require dusting off our historical glasses, and peering into the past.

A warning, too, about assuming too much comes from Michael Tkacik (Stephen F. Austin State University) in his effort to look at the other side of the arms control coin. 
Provocatively, he argues that proliferation can be and indeed is sometimes, promoted by arms control efforts. Stated another way, he suspects that more arms control might diminish nonproliferation endeavors. An American-Russian accord to cut back warheads in a putative START III accord, for example, might well diminish attention to and resources for a broad range of nonproliferation undertakings. Fewer weapons do not necessarily mean that proliferation halts or slows, and may actually have the inverse effect. Tkacik's logic warrants close attention. Clearly, at a time when terrorist access to weapons of mass destruction has heightened urgency, nonproliferation may gain greater credence rather than arms control accord between states. After all, arms control agreements are made between states, and usually large and strong ones; proliferation of all kinds of weapons, however, is most perilous when occurring in, around and through failed states, and benefiting end users with extremist agendas.

These five principal articles remind us that the future of international politics will involve and rest on a state-centered system, albeit with states far less assured and dominant. Thus far, theory has not "caught up" with fundamental changes, and the adaptation of the state to a new milieu continues apace. Much of our understanding of the new will require looking at the old, and history has a great deal to teach us about the genesis of today's European democracies or about the kinds of behavior in which our principal institutions engage.

In our Review section of Volume 39, No. 1 are Caroline Hughes' essay about globalization and human rights and Alison Millet McCartney's assessment of post-Cold War German foreign policy as well as our usual survey of individual works of particular importance. Hughes' piece carries through with similar questions evident in the rest of this issue - the relationship of the state vis-à-vis NGOs, international organizations and other actors in the realm of human rights. Is the topic of human rights, Hughes asks pointedly, a "...purveyor of dominance rather than a discourse of resistance [?]" Globalization, she implies, offers little in the way of "enlightenment" and looks suspiciously like a stalking horse for hegemony, unless freedom can be combined with authority to support better living standards. This is a tough message, but vital to consider as new generations of potential terrorists are born and raised in a world that seemingly cares not at all.

And, although about a major European state and the interplay of domestic politics and foreign policy, McCartney's take on German post-Cold War international relations contains parallel messages. German power and interests are not fully or principally explanatory, she infers from literature under review; "domestic politics, history and norms also play a crucial role in defining and making choices." Whether states define interests, or other factors form and mold interests that limit the range of state behavior, is an interpretive dilemma suggested by McCartney's review.

As always, the articles and review essays of International Politics feature and focus on questions that stick with you. The state and its future, other actors as rivals or servants of the state, the role of history as an explanation of the present, and norms embedded in globalization - these are but a few of the deep and pervasive issues that this issue considers in this period of international tension and violence. Not light reading, but essential for informed debate. 